\title{
\begin{tabular}{l|l} 
Mibraries & DSpace@MIT
\end{tabular}
}

\author{
MIT Open Access Articles
}

Introduction of hydrogen fuel cell vehicles: prospects and challenges for Malaysia's transition to a low-carbon economy

The MIT Faculty has made this article openly available. Please share how this access benefits you. Your story matters.

As Published: https://doi.org/10.1007/s11356-019-06128-4

Publisher: Springer Berlin Heidelberg

Persistent URL: https://hdl.handle.net/1721.1/131396

Version: Author's final manuscript: final author's manuscript post peer review, without publisher's formatting or copy editing

Terms of Use: Article is made available in accordance with the publisher's policy and may be subject to US copyright law. Please refer to the publisher's site for terms of use. 


\section{Introduction of Hydrogen Fuel Cell Vehicles: Prospects and Challenges for Malaysia's Transition to a Low Carbon Economy}

Cite this article as: Abul Quasem Al-Amin, Brent Doberstein, Introduction of Hydrogen Fuel Cell Vehicles: Prospects and Challenges for Malaysia's Transition to a Low Carbon Economy, Environmental Science and Pollution Research, doi: 10.1007/s11356-019-06128-4

This Author Accepted Manuscript is a PDF file of a an unedited peer-reviewed manuscript that has been accepted for publication but has not been copyedited or corrected. The official version of record that is published in the journal is kept up to date and so may therefore differ from this version.

Terms of use and reuse: academic research for non-commercial purposes, see here for full terms.

http://www.springer.com/gb/open-access/authors-rights/aam-terms-v1 


\title{
Introduction of Hydrogen Fuel Cell Vehicles: Prospects and Challenges for Malaysia's Transition to a Low Carbon Economy
}

\author{
Abul Quasem Al-Amin ${ }^{\text {abcd* }}$ \& Brent Doberstein ${ }^{\text {c }}$ \\ ${ }^{a}$ Department of Urban Studies \& Planning, Massachusetts Institute of Technology, Boston, USA \\ ${ }^{\mathrm{b}}$ Institute of Energy Policy and Research (IEPRe), Universiti Tenaga Nasional, Kajang, Malaysia \\ ${ }^{c}$ Department of Geography and Environmental Management, University of Waterloo, Waterloo, \\ ON Canada \\ ${ }^{\mathrm{d}}$ Institut Sultan Iskandar, Universiti Teknologi Malaysia, Johor Bahru, Skudai, Malaysia \\ * Corresponding author's email: amin.cantt@gmail.com; qalamin@uwaterloo.ca, \\ Tel: +1 (226) 5069710
}

\begin{abstract}
Alternative energy policies targeting the adoption of hydrogen fuel cell vehicles (HFCVs) could have significant positive impacts on Malaysia's ability to meet both its carbon reduction goal and its energy security needs. The transport sector generally contributes heavily to carbon emissions, and is also difficult to decarbonize because of the costs associated with many greener options. This study explores the possibility of decarbonizing the Malaysian transport sector by promoting the use of hydrogen vehicles, and analyzes the adoption challenges and economic obstacles (especially public acceptance) associated with introducing HFCVs. This paper contends that the adoption challenges of this new technology can be overcome through the use of development strategies outlined in this paper. This study also addresses the regulatory framework that Malaysia (and other countries) might use to overcome common policy adoption challenges of HFCVs.
\end{abstract}


Keywords: Low Carbon Society, Hydrogen Fuel Cell Vehicles, Economic Barriers, Policy, Renewable Energy, Transportation

\section{Contents}

1. Introduction

2. Hydrogen Fuel Cell Vehicles: A Review

3. Methodological Approach

4. Results and Discussion

5. Discussions and Policy Implication

6. Conclusion

7. Acknowledgement

8. References

\section{Introduction}

Low carbon sustainable development is an increasingly popular topic as climate change becomes increasingly obvious. The landmark Paris Agreement of $2015^{1}$ (COP21) came in the wake of mounting evidence showing that climate change is caused primarily by human activity (Tollefson \& Weiss, 2015; COP21, 2015). COP21 ended with an agreement endorsed by delegates from 195 nations to decarbonize the global economy as part of a strategy to limit temperature rise to $1.5^{\circ} \mathrm{C}$ over the next hundred years (Rasiah et al., 2016). Among other things, COP21 called for climate action by local governments, including low carbon technology development and technology transfer (Sarkar et al., 2019).

\footnotetext{
${ }^{1}$ The United Nations Conference on Climate Change (COP) in 2015 held since 1995 under the framework of the United Nations Framework Convention on Climate Change (UNFCCC).
} 
Growing concern over climate change has motivated a great interest in alternative sources of energy (Nowotny et al., 2018). The Marrakech Proclamation of 2016 (COP22) set a framework to move the global economy to a low carbon platform by 2050 (Rasiah et al., 2017). However, this an incredibly ambitious goal that has not been accompanied by a suitable roadmap for the development of green energy technology and its diffusion (Rasiahet al., 2018). The achievement of such a goal requires an unprecedented scale of innovation and technological momentum (European Parliament, 2016). Also, since the countries that signed the Paris Agreement are not legally bound to decarbonize their economies, a lot of uncertainty remains, and it is not clear how local governments will be able to implement low carbon pathways and develop and diffuse green technologies on their own (Bataille et al., 2018; Den Elzen et al., 2016).

COP21 sought to set guidelines to promote the diffusion and transfer of technology, accounting for the financing required to develop low carbon energy equipment for the transportation, energy and industrial sectors, as well as formulating a climate mitigation roadmap for local governments (Rasiahet al., 2018). COP21 and its subsequent linked events should have done more to create a roadmap for the development of new technologies which support a low carbon society (Christoff, 2016). Unfortunately, none of the most recent COP meetings (COP21, and COP22, as well as COP23 held in Bonn, Germany), succeeded in doing this.

At the COP23 Bonn meeting, delegates debated alternative option to evaluate the applicable costs of moving towards sustainable technologies, and ways to diffuse these technologies to developing countries (UNFCCC, 2017). Delegates also discussed the need to supplement existing global mechanisms and institutions with a 'Technology Mechanism' (established in 2010 to support efforts to accelerate and enhance action on climate change), the 'Technology Executive Committee' (the Technology Mechanism's policy arm) and the 'Climate Technology Centre and Network' (the implementation arm of the mechanism) (Bulkeley \& Newell, 2015). While the revised document, draft decision 1/CP.23 produced by the Bonn meeting included the need for support and resource transfer from developed nations to developing nations based on Paris Agreement obligations ${ }^{2}$, there was no mention made of the need for enhancement of domestic research and development capabilities, access to sound technology options, or

\footnotetext{
${ }^{2}$ The obligations included the Paris Agreement's agenda on global response to climate change beyond 2020 and pre-2020 commitments and actions, differentiated responsibilities and Parties' (e.g. nations signed to the Agreement) efforts to cover adaptation, mitigation and means of implementation addressing new technology framework, including its guidance to the technology mechanism in enhancing global actions.
} 
support for strengthening cooperative action and collaboration among and between developing nations (UNFCCC, 2017). This paper contends that the concept of sustainable development needs to focus on all aspects of technology development and deployment, including research and development, cooperation, commitment and funding for sustained action.

A wide range of green and low carbon technologies already exist that are increasingly used to generate energy (e.g. solar panels, windmills, biomass processors, and hydrogen fuel cells) but much more is needed to ensure all countries can benefit from these (Fankhauser \& Jotzo, 2018). The development of green technologies should not only target new sources, but also cheaper and more environmentally friendly versions of existing technologies (Fridahl \& Linn, 2016). It is obvious that more collaborative negotiations (e.g. North and South nations, signatories to the Paris Accord, etc.) would go a long way to achieving that goal (Rasiah at al., 2017). Although all signatories to the Paris Agreement have by now submitted their Intended Nationally Determined Contributions (INDCs) ${ }^{3}$ to the United Nations Framework Convention on Climate Change (UNFCCC), much more needs to be done to ensure that national and local governments will introduce technologies (cities to nationwide) to facilitate the switch of energy sources from fossil to non-fossil fuels to respond to climate change (Reckien et al., 2018). Necessary policy advice for countries can range from diffusion mechanisms for low carbon fuel technologies to developing economies, to the development of entirely new sources of low carbon energy (Randolph, \& Masters, 2018). Detailed cost-benefit analyses of various options would be enormously helpful for countries that have not yet made major investments in low carbon fuel technologies.

Another key theme explored in COP21 was a call for a 'green economy agenda' by local governments, and guidance on the pathways governments should follow in providing (i) transportation, (ii) electricity and (iii) industry operations, the three sectors which contribute most heavily to carbon emissions and global warming (Tolliver et al., 2019). One of the major obstacles to making a transition to a green economy is that carbon emissions from upper-middle income countries are largely due to industrialization, energy utilisation and rapid motorization (Thiele, 2019; De Jesus \& Mendonça, 2018; Roberts et al., 2018). Carbon emissions from the

\footnotetext{
${ }^{3}$ Intended Nationally Determined Contributions (INDCS) is a commitment by counties who signed Paris Agreement 2015, under UNFCCC for reductions in greenhouse gas emissions to a certain level over time.
} 
transport sector in non-OECD countries are growing faster than in OECD countries (Ambrose et al., 2017).

By 2040, without any mitigation efforts, energy demand for transportation is projected to be $61 \%$ of the total demand in non-OECD countries (EIA, 2017). Developing countries thus not only need to meet increasing demand for motorization, but doing so while also making progress on carbon emissions reduction goals. A number of these countries are therefore looking for a sustainable pathway framework which has viable options for cleaner fuels, energy security and energy-efficiency technology to reduce carbon emissions in line with the Paris Agreement. Many recent contributions to the scientific literature have addressed these issues (Randolph, \& Masters, 2018; Emonts et al., 2017; Preuster et al., 2016; Singh et al., 2015; Silva et al., 2014; and Bae \& Cho, 2010).

In light of this, Malaysia's move to a lower carbon society may require interventions to stimulate the adoption of alternative technologies with low or zero carbon emissions. This will not be an easy task as long as conventional fuel cell vehicles dominate the worldwide transportation sector. The achievement of low carbon adoption also requires supportive clean energy transition policies and technological momentum. Widespread sustainable development and green motorization requires answers to the following key queries: (i) how should the low carbon society be framed, and what is its function within the scope of 'sustainable cities'; (ii) how is a low carbon society possible given the existing challenges; and (iii) currently, how many alternatives are there? Malaysia's concern around these issues is echoed by other advanced and transitional economies.

As declared at the Paris Accord, Malaysia is committed to a $45 \%$ reduction in per capita carbon emissions by 2030 (low carbon pathways) as compared to 2005 levels, which is a substantial amount (Rasiah et al, 2017). Accordingly, Malaysia needs to simultaneously address an increasing demand for cars and also its Paris Agreement carbon reduction goals. Thus, one key question is how should Malaysia incorporate alternative technologies (e.g. green transportation) into its green pathway of out different pathways to the future?

Progress has been made with the limited adoption of alternative technologies for green transportation such as plug-in electric and hybrid vehicles (Zambrano-Gutiérrez et al., 2019). However, there are a number of shortcomings of such technologies, including less power and acceleration as compared to traditional vehicles (Ambrose et al., 2017). This is due to their 
smaller internal combustion engine and lighter weight to maximize engine efficiency. Hybrid vehicles are made with lighter-duty components which provide less support in the suspension system compared to conventional vehicles (VanGelder, 2017). Moreover, maintenance of the dual compulsion engine systems is expensive. Overall, hybrids' mechanical proficiency and performance is generally less than conventional vehicles (Arun et al., 2018). Comparatively, plug-in electric vehicles also have a number of concerns when compared to traditional vehicles, such as their shorter driving range due to high-tech drawback on the battery (Wanitschke, \& Hoffmann, 2019; Manthiram, 2016). The average distance that can be traveled by plug-in electric vehicles is about 160-200 kilometers. Vehicles that can travel further, up to 450 kilometers, are currently very costly (Ahmed et al., 2016). Plug-in electric vehicles generally also take a long time to recharge compared to simply filling up with conventional fuel, and many require costly home renovations to support home charging systems (Gnann et al., 2018). Considering this, one potential alternative is to shift to hydrogen fuel cell vehicle (HFCV) ${ }^{4}$ transport systems (Moriarty \& Honnery, 2019). This would address the challenges of power, output and battery constraints faced by plug-in electric and hybrid vehicles. Moreover, HFCVs are emission free, an advantage over plug-in electric, hybrid and conventional fuel vehicles that rely on fossil fuels.

Recent studies show that Malaysia could reduce its carbon emissions by up to $114 \%$ mtoe (million tons of oil equivalent) by substituting 50\% of existing conventional vehicles to hydrogen fuel cell vehicles (Ambrose et al., 2017), so it is important for policy makers to think about the hydrogen fuel cell option in Malaysia. However, widespread adoption of HFCVs in Malaysia presents challenges in three broad areas: (i) cost; (ii) technology; and (iii) public preference. Currently there is no HFCV infrastructure available in Malaysia, yet a workable infrastructure (e.g. a network of distribution for hydrogen, hydrogen production and sales, refueling of hydrogen station, hydrogen transport and maintenance facilities) is a pre-requisite before successful commercialization of automotive fuel cell technology such as HFCVs. Before HFCVs can be introduced, additional issues such as hydrogen regulatory frameworks and safety standards, subsidy/incentive options, affordability, capacity support systems, and strategies for replacing conventional vehicle over time need to be in place. In terms of technology, many

\footnotetext{
${ }^{4} \mathrm{~A}$ conventional vehicle is that which uses an internal combustion engine in which combustion of fuel (usually petrol and diesel) generates by-products including greenhouse gases (GHG). Unlike conventional vehicles, hydrogen fuel cell vehicles (HFCV) technology combines oxygen and hydrogen to generate electricity to power an electric motor, with water as a combustion byproduct. HFCVs run like electric vehicles ("EVs") but there are several technological differences in fuel, fueling procedures and conversion processes (e.g. like natural gas station: NGV) which need to be developed by the introducing country.
} 
innovation and R\&D-related issues remain, particularly cost of production, cost of membrane, scaling up to mass production, a cheaper component for the catalyst, cheaper energy conversion, safety, market-based competition, and public awareness programs are required to adapt to this new technology. Finally, HFCVs require careful consideration of macroeconomic issues, economic obstacles, acceptance of new technologies and uncertainties and risks.

This study addresses public preferences toward HFCVs in Malaysia from the viewpoints of stakeholders, policymakers and society, in order to understand: what are the technology adoption challenges and barriers of introducing HFCVs in the transport sector? This poses the following key sub-question: what are the economic obstacles that affect public acceptance of new technologies and public preferences towards shifting to HFCVs? Malaysia's conventional transportation system and its correlating energy demand is expected to continue unless a sustained intervention takes place. Therefore, one key concern of this paper is how to meet, simultaneously, increasing demand for motorization in an advanced developing country while fostering a clean energy transition for future environmental sustainability. Applying HFCVs nationwide in Malaysia would help the country to substantially reduce emission levels, moving towards achieving the 2030 committed target as one of the best alternative options. This study contributes new findings to research on the adoption challenges of HFCVs and suggests how these can be overcome through the use of several strategies. This study also addresses the regulatory framework that Malaysia and other countries might use to overcome common policy adoption challenges which was initiated in previous research on upcoming and new technologies such as HFCVs.

\subsection{Hydrogen Fuel Cell Vehicles: A Review}

A proper transportation system is part of economic prosperity and development and cannot be ignored in order to promote economic and environmental sustainability. It is obvious from the literature that increased emissions due to consumption of conventional fossil fuels is causing environmental degradation (Bekun etal., 2019; Akhatar et al. 2014; Andres et al, 2012; Gutiérrez \& Méndez, 2012; Timilsina \& Shrestha, 2009; Hensher, 2008). Fossil fuels are presently the major source of energy for Malaysia's transportation system (Oh et al., 2018). Numerous studies have raised concerns over the environmental sustainability of such a situation and suggest alternative options with alternative energy sources (Smith, 2019; Baland et al., 2018; Rasiah et 
al, 2017; Manthiram, 2016; Timilsina and Shrestha, 2009; Maclean et al., 2004; Bonnafous \& Raux, 2003). The concept of a greener economic system has been around for a long time, however, the concepts of low carbon and smart transport options are still relatively new (Dia et al., 2019; O’Dwyer et al., 2019). Questions remain over how to minimize cost factors for low carbon and smart transport systems, and the strategies needed in order to decarbonize the national economy to achieve a greener low carbon society that addresses economic obstacles ${ }^{5}$ and societal needs (Ekins, 2010).

Numerous studies indicate the importance and promise of the hydrogen fuel cell economy, and associated vehicles and transport systems (Staffell et al., 2019; Ajanovic, \& Haas, 2018; Emonts et al., 2017; Ambrose et al., 2017; Preuster et al., 2016; Singh et al., 2015; Silva et al., 2014; Bae \& Cho 2010). Faced with the environmental externality due to a lack of alternative options, many authors suggest it is time for the transportation sector to replace internal combustion engines (Ambrose et al., 2017; Moliner et al., 2016; Eberle, Müller \& von Helmolt, 2012; Adams \& Chen, 2011; Ball \& Wietschel, 2009; Marbán \& Valdés-Solís, 2007; Cropper et al., 2004). Thus, policymakers must explore how to develop an economically viable energy infrastructure to support sustainable transport systems using the power of hydrogen (Ambrose et al., 2017). Some studies point out that even though there has been progress made with alternative technologies, there are still shortcomings like less capacity in terms of technological constraint (e.g. material/energy/output), materials-related challenges for electrical energy storage, and zero emission concerns that must be addressed in order to replace conventional fossil fuels (Ambrose et al., 2017; Ahmed et al., 2016). The lessons learned from the adoption of electric vehicles (EVs), including lessons related technology, infrastructure, vehicle performance, price and costs to end users (Chen \& Perez, 2018; Raslavičius et al., 2015; Hannan et al., 2014; Narayanan et al., 2012; Whittingham, 2008) can provide valuable guidance for how to facilitate the adoption of HFCVs (Nian et al., 2019; Li et al., 2016; Beeton \& Meyer, 2014).

Choosing a sustainable transport pathway is crucial for Malaysia to meet its projected demand for cars while avoiding a massive rise in emissions that might prevent the country from reaching its 2015 Paris Agreement target. Since the 2000s, Malaysia's carbon emissions have been increasing at an alarming rate (Figure 1, World Bank, 2016). Thus, there is a question mark on

\footnotetext{
${ }^{5}$ Obstacle/issue is that a development which connects with technology and societal needs, unsure that market-driven forces (e.g. prices) may not be achieved for the society within the existing technologies and developments unless further technological interventions taken place.
} 
how Malaysia will be able to offer an excellent example of a developing country meeting its INDC by 2030. The country is also expected to increase conventional transport capacity with an expected future per capita vehicle ownership growth rate of 5.9\% annually (Figure 2) (Economic Planning Unit, 2015). Recent findings on transport mobility suggest continued ownership growth over 2018-2030 time period (Ambrose et al., 2018). A 2015 study (IEA, 2015) on the global status of HFCVs indicated that 150 million HFCVs sales are expected globally by 2050, which will reduce fossil fuel dependence and contribute to energy security. Although HFCV technology has advanced significantly in recent years, some obstacles remain, including; overcoming public misconceptions about HFCVs technology and infrastructure (Ambrose et al., 2018); the need for regulatory frameworks; energy prices and economic challenges; the need for more technological development; cost to user public perception, and; entrenched preferences and possible sociocultural obstacles to the adoption of HFCVs (Ambrose et al., 2017). While some studies have found evidence of public acceptance of HFCVs, attitudes, and perceived behavior control, subjective norms and its related matters (Chen et al,, 2016); still country specific lacking of adoption issues toward the HFCVs is important to figure out.

Figure 1: CO2 Emission of Upper Middle Income Countries, 1960 - 2012

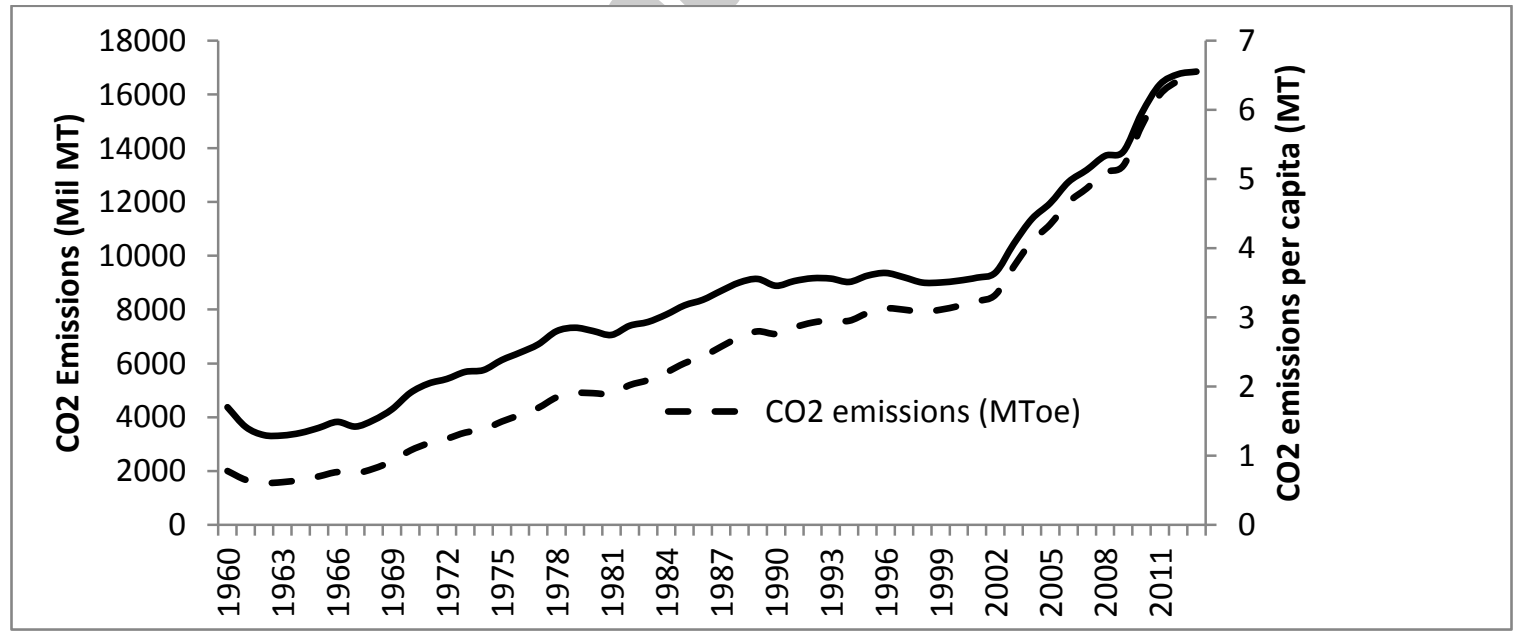

Source: World Bank, 2016

It is obvious that public purchase intentions, attitudes, purchase behaviors and acceptance of HFCVs can vary significantly depending on a country's economic position and level of economic development, and its comparative advantage of resources, all of which influences 
consumers (Chen et al., 2016; Albayrak et al., 2013; Barber et al., 2012). Some earlier studies have addressed public acceptance and attitudes (Fast, 2013; Devine-Wright, 2007; Dinse, 1999); however, those studies did not address the scope of attitudinal research on purchase intentions or purchase behaviors and how intended use influences certain behavior or perceived behavioral control (e.g. perception of impact) ${ }^{6}$ (Albayrak et al., 2013; Axsen \& Kurani, 2013; Barber et al., 2012). Purchase behavior mostly depends on customer satisfaction (Barber et al., 2012, Wang et al., 2000; Stobart, 1999). Three attitudinal variables, purchase behaviors, environmental consequences, and perceived risks \& individual preferences for new innovation, are commonly connected to public preferences for new transportation technologies. Some studies also indicated that the purpose of intention and role of attitudes to the purchase intention depends on the meaning of attitudes, perceived behavioral control and subjective norms (Ambrose et al., 2017).

The skepticism that people might feel about the risks of new technology maybe not be disadvantageous for HFCVs to be successful in the market, however perceived risks relating to vehicle performance, vehicle safety and pathways may impact public acceptance (Axsen \& Kurani, 2013). Without doubt, HFCV is a new area that requires much study specific to the Malaysian context. This study is an initial contribution which examines the prospects and challenges associated with a shift to HFCVs in Malaysia.

Figure 2: Vehicles registered in 1000s of people in Malaysia, 2000-2013

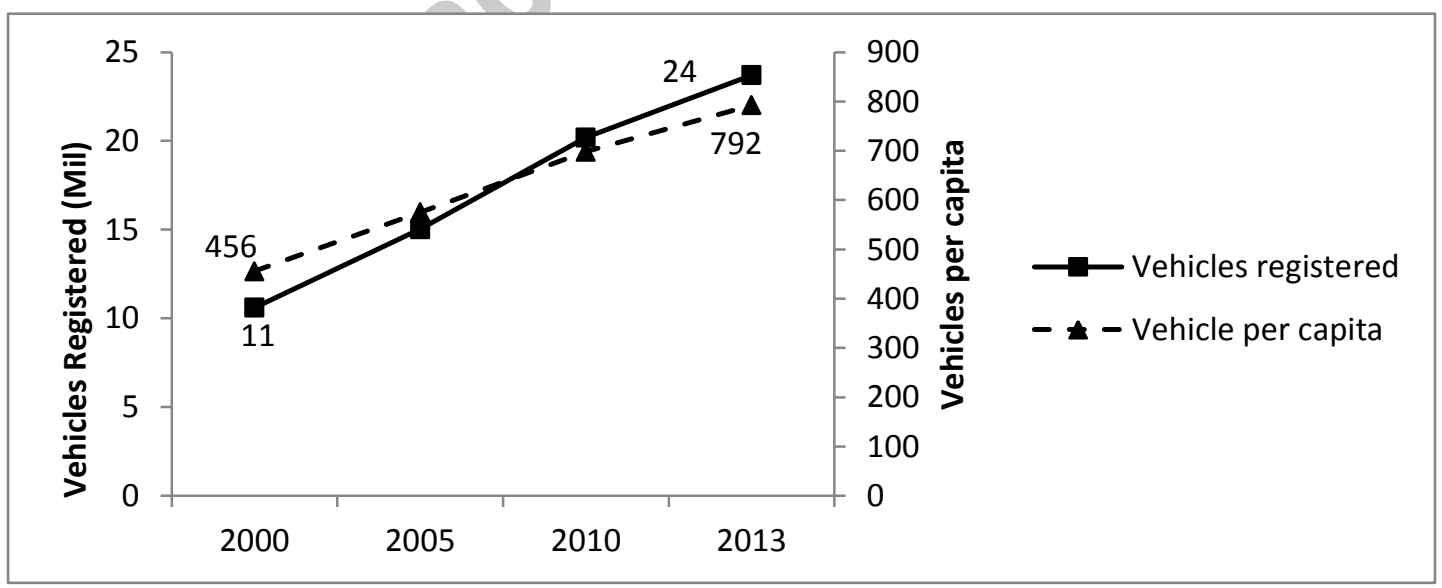

Source: Economic Planning Unit, 2015

\footnotetext{
${ }^{6}$ Benefit intention on the awareness of the environment may influence consumer purchase intentions, and once large numbers of people understand the benefit of HFCV for the environment then the purchase intentions of large numbers of consumer may influence societal desires to embrace HFCV (Chen et al., 2016; Albayrak et al., 2013).
} 


\section{AUTHOR ACCEPTED MANUSCRIPT}

This paper firstly reviews the literature on the challenges of HFCVs related issues for a transition to a low carbon economy. Then, the paper quantified the public preferences and likely barriers toward HFCVs adoption. The paper concludes with policy recommendations for implementing HFCVs managing demand and supply side strategies that simultaneously follow low carbon pathways and other national sustainability agendas.

\section{Methodological Approach}

This study adopts a 'policy strategy' approach that uses survey-based research techniques. The 'policy strategy' employed here used quantitative Structural Equation Modelling (SEM) to explore the implications of strategies and economic obstacles to Malaysian public acceptance of and public preferences for hydrogen fuel cell vehicles (HFCVs). Methodological steps included (a) research hypotheses, (a) selection of a study area, (c) decisions about data sources and sampling techniques, and (d) questionnaire design, including model fitness, to conform to the study goals.

\subsection{Research hypotheses:}

This study considered five hypotheses about understanding the scope of a sustainable city blueprint toward a low carbon society and the role potentially played by introducing HFCVs. The five hypotheses which proposed relationships within selected study variables were used to obtain research outcomes about HFCV concerns are as follows:

H1 Awareness (AWAR) about HFCV benefits has a positive impact on green transport technology-related values,

$\mathrm{H} 2$ Environmental knowledge (KNW) has a positive impact on awareness (AWAR) about HFCV benefits,

H3 Green transport technology-related values has a positive impact on environmental knowledge $(\mathrm{KNW})$,

H4 Awareness (AWAR) about HFCV benefits has a positive impact on purchasing behavior (BEHAV) on HFCV, and

H5 There is a positive relationship between purchasing behavior (BEHAV) and environmental knowledge (KNW) on HFCV for the purchase intention (PI). 


\section{AUTHOR ACCEPTED MANUSCRIPT}

\subsection{Study Area and Location Choice:}

This study considered Putrajaya (the administrative capital), and Kuala Lumpur (business capital) of Malaysia and its associated territories as a case study to identify economic obstacles to public acceptance of new technologies such as HFCVs. These two areas are some of the largest zones in Malaysia in terms of gross domestic product (GDP) and population (DOS, 2017). Those two areas are considered to be some of the most densely populated areas in the country and average vehicle ownership is about 9.425 for every 10 people as a ratio which is very important to execute research scope on greener motorization (Ambrose et al., 2018).. Additionally, dense motorization areas are important as a case study since they will be an important test case for achieving the Malaysian 2030 commitment via alternative options (Ambrose et al., 2018). Literature suggests that transportation research should be done initially in urban areas which are considered the status quo of socio-economic trends, infrastructure and population (Ambrose et al., 2017). Thus, Putrajaya and Kuala Lumpur, and associated territories, are the best choices for pilot studies that will help researchers understand the study characteristics better. Likewise, the locations we chose by purposive sampling were dense vehicle use areas which are essential to facilitate enhanced insight about new transportation alternatives and their magnitudes, from which lessons could be drawn and improved suggestions made for other urban areas and all over gradually. The maps of Putrajaya and Kuala Lumpur region are shown in Figure 3.

\subsection{Data Sources and Sampling Technique:}

Primary data were collected from structured surveys and semi-structured interviews held between October 2017 and May 2018. For the structured surveys, 338 written questionnaires were distributed (randomly distributed with a purposive sample) to existing vehicle owners ${ }^{7}$ in the age categories of 18-30, 31-45, 46-60, 61 and above. Of the total 338 questionnaires that were distributed, 232 were completed (68.6\%). The structured surveys were completed by both online and face-to face modes. In contrast, 48 people took part in the semi-structured interviews out of 58 people were contacted $(82.8 \%)$. Semi-structured interviews were conducted only faceto-face with an average completion time of 50-55 minutes. A total of 48 questionnaires were not

\footnotetext{
${ }^{7}$ We used discrete categorical random and purposive sampling on the basis of some qualitative properties where all ranges of existing sample vehicle owners, e.g. professional, business people, taxi company owners, student, worker, driver etc. have been considered.
} 


\section{AUTHOR ACCEPTED MANUSCRIPT}

completed fully and 58 questionnaires were not responded to correctly so these were excluded from the study. Ten semi-structured interviews were excluded from the study because of incomplete interviews

\subsection{Questionnaire Design:}

The structured survey consisted of sections A and B. Section A asked about respondents' socio-economic characteristics: gender, age group, race, educational qualification, and monthly income. Section B asks about respondents' environmental values and related subject matters such as environmental concerns based on morals and ethics, attitudes, environmental knowledge and awareness, purchase intentions, purchase behaviours, knowledge about environmentallyfriendly brands, product quality, safety and design, subjective norms, uses of alternative fuel, and the performance and preference of environmental-friendly cars in Malaysia. Most questions in section B used a 5-point Likert scale representing a range between (1) strongly disagree and (5) strongly agree. Semi-structured interviews probed interviewees' social values, their related/ individual preferences, and the challenges/obstacles that interviewees identified when considering whether to buy or use an environmental friendly vehicle such as a HFCV to support the transition to low carbon society in Malaysia. The scope of issues covered in the semistructured interviews included environmental sustainability challenges, infrastructure development issues, economic obstacles to sustainability, and non-technology or non-cost factors such as the types of support required directly and indirectly from policy makers or government.

\section{Results and Discussion}

\subsection{Descriptive Statistical Analysis}

A total of 232 surveys were completed, for a response rate of just over 68.6 percent. Respondents were 51.7 percent male and 48.3 female. The ethnic backgrounds of respondents were 13.4 percent Malay, 27.2 percent Indian, 55.6 percent Chinese and 3.9 percent. The greatest number of respondents (48.7\%) were in the age category between 31-45 years old. 28.9 percent held graduate degrees followed by 19.4 percent with an undergraduate diploma, 27.2 percent with lower secondary school completion, 18.1 percent with higher secondary school completion, 6.5 percent with post-graduate degrees, and 0 percent with only primary education or no formal 
education. In terms of income, respondents' largest income group was RM2001-4000 [US\$ 470940] (40.1 percent) followed by RM4001-6000 [US\$ 940-1,410] (37.1 percent) (Table 1).

Figure 3. Maps of Putrajaya and Kuala Lumpur regions of Malaysia
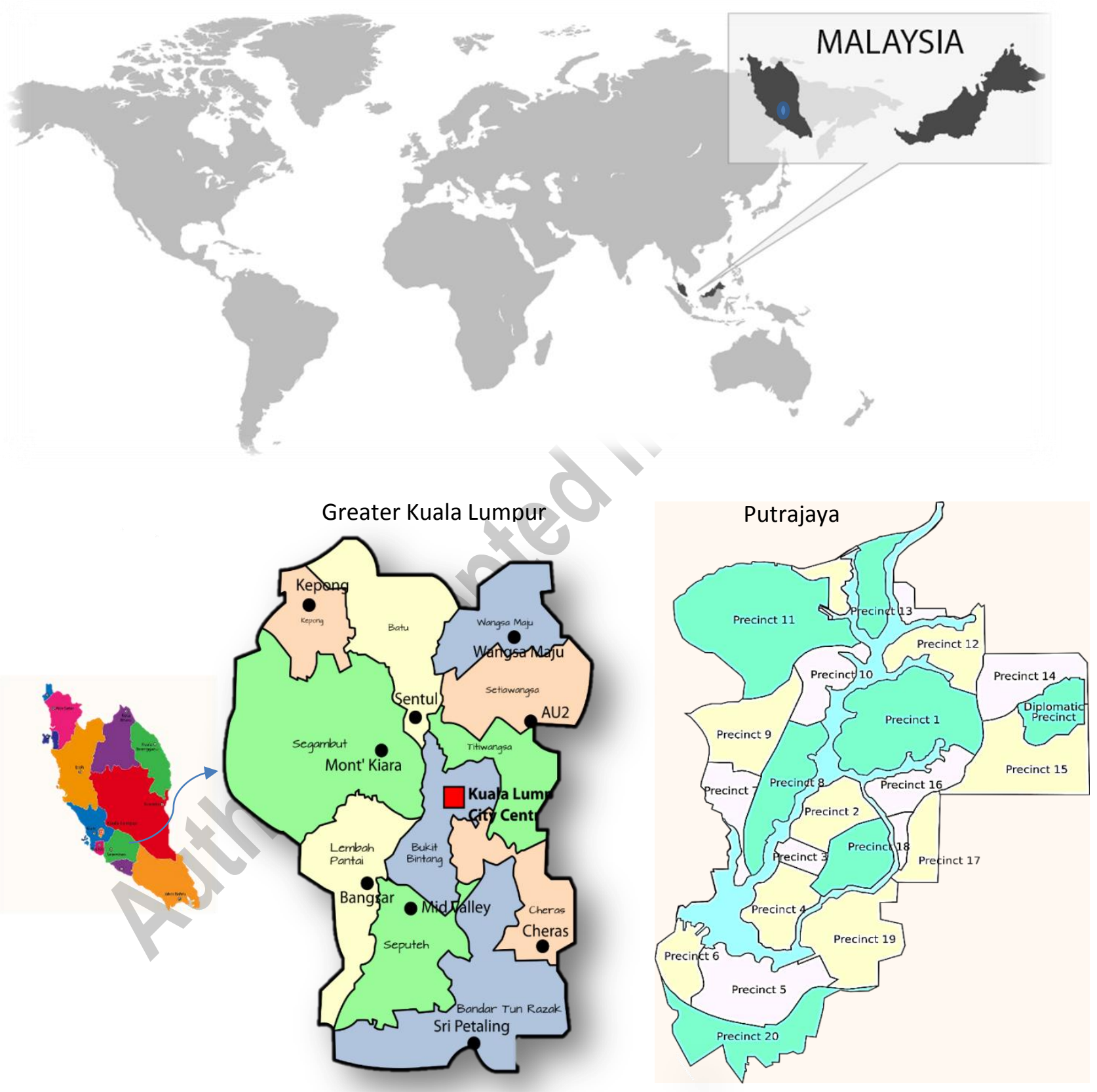


\section{AUTHOR ACCEPTED MANUSCRIPT}

Table 1. Breakdown of Respondents' Demographic Information $(N=232)$

\begin{tabular}{|c|c|c|}
\hline Variables & Frequency & Percentage $(\%)$ \\
\hline \multicolumn{3}{|l|}{ Gender } \\
\hline Male & 120 & 51.7 \\
\hline Female & 112 & 48.3 \\
\hline \multicolumn{3}{|l|}{ Age } \\
\hline $18-30$ years & 81 & 34.9 \\
\hline $31-45$ years & 113 & 48.7 \\
\hline 46- 60 years & 32 & \\
\hline 61 years and above & 6 & 2.6 \\
\hline \multicolumn{3}{|l|}{ Race } \\
\hline Malay & 31 & 13.4 \\
\hline Indian & 63 & 27.2 \\
\hline Chinese & 29 & 55.6 \\
\hline Others & 9 & 3.9 \\
\hline \multicolumn{3}{|l|}{ Education } \\
\hline No formal education & 0 & 0 \\
\hline Lower secondary school & 63 & 27.1 \\
\hline Higher secondary school & 42 & 18.1 \\
\hline Diploma & 45 & 19.4 \\
\hline Graduate & 67 & 28.9 \\
\hline Post graduate & 15 & 6.5 \\
\hline \multicolumn{3}{|l|}{ Income } \\
\hline RM 2000 and less than (US\$ 470) & 19 & 8.2 \\
\hline RM 2,001- RM 4,000 (US\$ 470-940) & 93 & 40.1 \\
\hline RM 4,001- RM 6,000 (US\$ 940-1,410) & 86 & 37.1 \\
\hline RM 6,001- RM 8,000 (US\$ 1,410-1,882) & 18 & 7.8 \\
\hline RM 8,001 and above (US\$1,882) & 16 & 6.9 \\
\hline
\end{tabular}

*US \$1 = RM4.25 


\section{AUTHOR ACCEPTED MANUSCRIPT}

\subsection{Environmental Values, Knowledge \& Awareness}

Levels of environmental awareness, defined by several indicators in the survey, were addressed to measure respondents' overall environmental understanding. The results demonstrated that 47.8 percent of respondents are aware of environmental matters and 38.8 percent of respondents understand that a clean environment is important for all. 40.9 percent of respondents believe that use of conventional vehicles creates greater dependency on conventional fuels. 40.1 percent of respondents indicate that clean transportation is important to overcome existing air pollution caused by conventional transport (Table 2). 75 percent of respondents support the idea that an alternative energy system can help to reduce air pollution in urban areas. 67.7 percent of respondents believe that HFCVs, compared to conventional vehicles, can help with overall environmental sustainability.

\subsection{Awareness of Environmental Subject Matters}

The results also suggest that a fair number of respondents have some degree of awareness related to HFCVs' cost, safety, performance, appealing design, and comfort. Specifically, 61.2 percent would buy a HFCV if the cost is equivalent to a conventional vehicle, 56.5 percent would buy a HFCV if it is safer than a conventional vehicle, 56.9 percent would buy a HFCV even if the performance is weaker than a conventional vehicle [e.g. the performance of engine power of the conventional vehicle compared between 1500 cc and 2000 cc with equivalent HFCVs power], 60.8 percent would buy a HFCV even if it has a less appealing design, and 68.5

percent would buy a HFCV even if it is less comfortable (Table 3). According to the cumulative results, it is noticeable that a high percentage (68.5 percent) of the respondents (33.2 percent) favor the idea of possibly purchasing a HFCV based on perceptions of vehicle comfort compared to a conventional vehicle. 
Table 2. Values \& Environmental Knowledge

\begin{tabular}{|l|c|c|}
\hline \multicolumn{1}{|c|}{ Item(s) } & Frequency & $\begin{array}{l}\text { Percentage } \\
(\boldsymbol{\%})\end{array}$ \\
\hline A clean and tidy environment is important to me & 111 & 47.8 \\
\hline Conventional vehicles create air pollution & 90 & 38.8 \\
\hline Conventional vehicles create smog in cities & 95 & 40.9 \\
\hline $\begin{array}{l}\text { Conventional vehicles create greenhouse gases (GHG) such as } \\
\mathrm{CO}_{2}, \mathrm{NO}_{\mathrm{x}} \text { and } \mathrm{N}_{2} \mathrm{O} \text { that contribute to global warming and } \\
\text { climate change }\end{array}$ & 93 & 40.1 \\
\hline $\begin{array}{l}\text { Alternative energy systems can help to reduce air pollution in } \\
\text { urban areas }\end{array}$ & 95 & 75.0 \\
\hline HFCVs can help with overall environmental sustainability & 89 & 67.7 \\
\hline
\end{tabular}

Table 3. Factors Affecting HFCV Purchase Intentions

\begin{tabular}{|l|c|c|c|}
\hline \multicolumn{1}{|c|}{ Item(s) } & Frequency & $\begin{array}{c}\text { Percentage } \\
(\%)\end{array}$ & $\begin{array}{c}\text { Cumulative } \\
\text { Percentage* } \\
(\%)\end{array}$ \\
\hline $\begin{array}{l}\text { I would buy an HFCV if the cost is } \\
\text { equivalent to a conventional vehicle }\end{array}$ & 70 & 30.2 & 61.2 \\
\hline $\begin{array}{l}\text { I would buy an HFCV if it is safer than a } \\
\text { conventional vehicle }\end{array}$ & 69 & 29.7 & 56.5 \\
\hline $\begin{array}{l}\text { I would buy an HFCV even if the } \\
\text { performance is weaker than a conventional } \\
\text { vehicle }\end{array}$ & 67 & 28.9 & 56.9 \\
\hline $\begin{array}{l}\text { I would buy an HFCV even if it has a less } \\
\text { appealing design }\end{array}$ & 70 & 30.2 & 60.9 \\
\hline $\begin{array}{l}\text { I would buy an HFCV even if it is less } \\
\text { comfortable }\end{array}$ & 77 & 33.2 & 68.5 \\
\hline
\end{tabular}

*Cumulative percentage calculates the percentage of the cumulative frequency within each interval 


\subsection{Purchase Intention and Awareness on HFCV}

This study has considered five hypotheses that were tested to understand consumers' purchase intentions, and all five hypotheses were supported (Figure 4). Hypothesis H1 (e.g. awareness has a positive impact on values) suggests that there is a positive relationship between AWAR and values with an $r$ coefficient $^{8}$ value of 0.312 , meaning that the hypothesis that awareness and personal values influence the sample's intention to purchase HFCVs is supported at a significance level of 1 percent. Hypothesis $\mathrm{H} 2$ (i.e. that knowledge has a positive impact on awareness) is supported at a significance level of XX meaning that there is a positive relationship between KNW and AWAR with an $r$ coefficient of 0.241. This suggests that knowledge of environmental sustainability and awareness of environmental issues are closely related to having a positive purchase intention for HFCVs. Hypothesis H3 (e.g. values haves a positive impact on environmental knowledge) was found to have a positive relationship between KNW and values with an $r$ coefficient of 0.564 suggesting that these values are more influencial than those between KNW and AWAR.

This suggests that personal values are very important if there is awareness on environmental sustainability. Hypothesis $\mathrm{H} 4$ (e.g. awareness has a positive impact on behavior) was supported, so there appears to be a positive relationship between BEHAV and AWAR with an $r$ coefficient of 0.087 at a significance level of 1 percent. This suggests that awareness of environmental sustainability will have an influence in our sample on purchase behavior for HFCVs. Finally, hypothesis H5 (e.g. there is a positive relationship between behavior and knowledge) was found to be supported, so there is a positive relationship between BEHAV and KNW with an $r$ coefficient of 0.709 and a significance level of 10 percent. This means awareness of HFCVs and knowledge of environmental issues play a significant role in our sample on influencing purchase behavior (Table 4). These results are supported by related studies done by Kline (2010) and Schumacker \& Lomax (2004).

\footnotetext{
${ }^{8}$ The coefficient $(r)$ measures the direction and strength of a linear relationship between two variables $(Y=a x+b)$ within the valued range of between +1 and -1 .
} 


\section{AUTHOR ACCEPTED MANUSCRIPT}

Table 4. Hypotheses related to Path Coefficients of Purchase Intention

\begin{tabular}{|c|c|c|c|}
\hline No & Hypotheses & Coefficient $(\beta)$ & Remark \\
\hline H1 & AWAR<--- Values & 0.312 & Supported \\
\hline H2 & KNW <---AWAR & 0.241 & Supported \\
\hline H3 & KNW<--- Values & 0.564 & Supported \\
\hline H4 & BEHAV<---AWAR & 0.087 & Supported \\
\hline H5 & BEHAV<---KNW & 0.709 & Supported \\
\hline
\end{tabular}

Figure 4. Relationships between study hypotheses

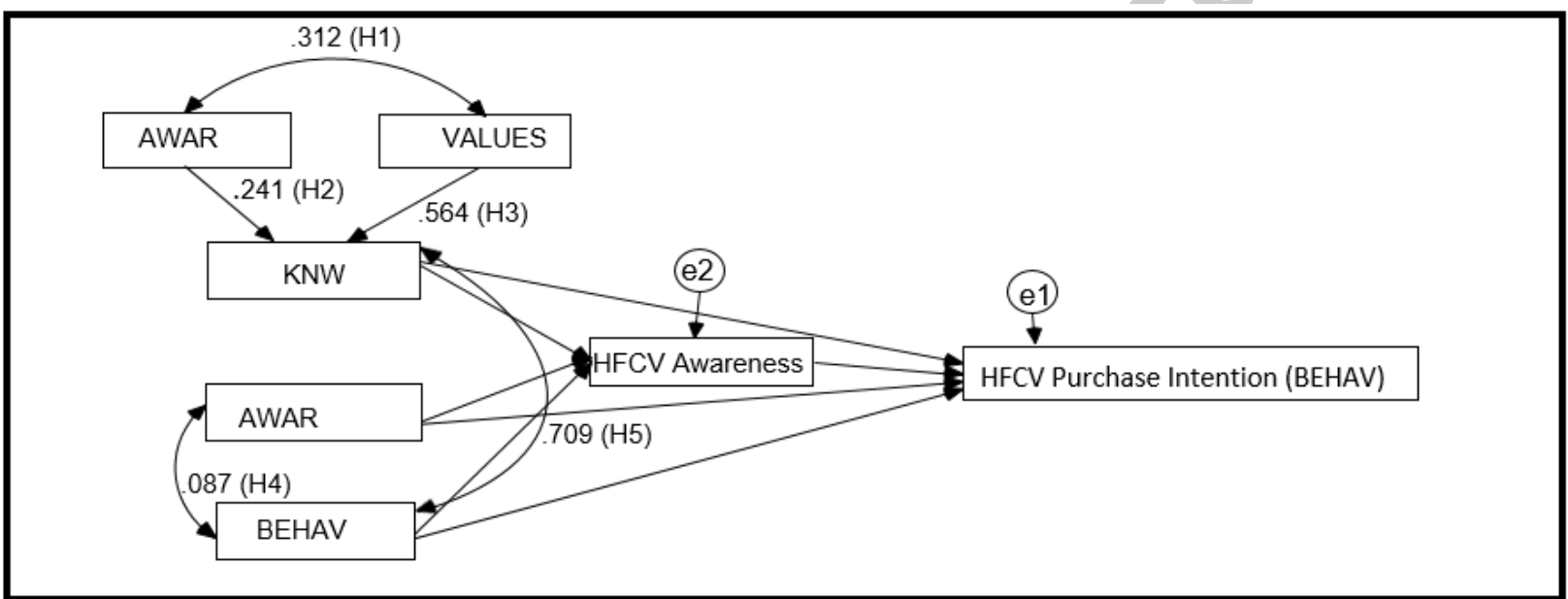

There are several key relationships found for purchase intention (PI) and purchase behavior (PB) in the study model, which are associated with AWAR and values, KNW and AWAR and BEHAV \& KNW (Figure 5). The study found a significant relationship between personal values and awareness of HFCVs due to the knowledge that conventional vehicles create air pollution, and that conventional vehicles create greater dependency on conventional fuels, as shown by e1 $(\beta=0.56)$, e2 $(\beta=0.10)$ and e3 $(\beta=0.46)$. Additionally, in this study, knowledge of environmental values appears to play a significant role in influencing purchase behavior through knowledge that conventional vehicles create greater dependency on conventional fuels which in turn cause greenhouse gas emissions, as shown by e3 $(\beta=0.71)$, e1 $(\beta=0.56)$, and e2 $(\beta=$ 0.24). Thus, the comparative (dimensional) values of AWAR, KNW and BEHAV show the future impacts to have HFCVs by the purchase intention. 
Figure 5. Relationships between Purchase Intention and Awareness

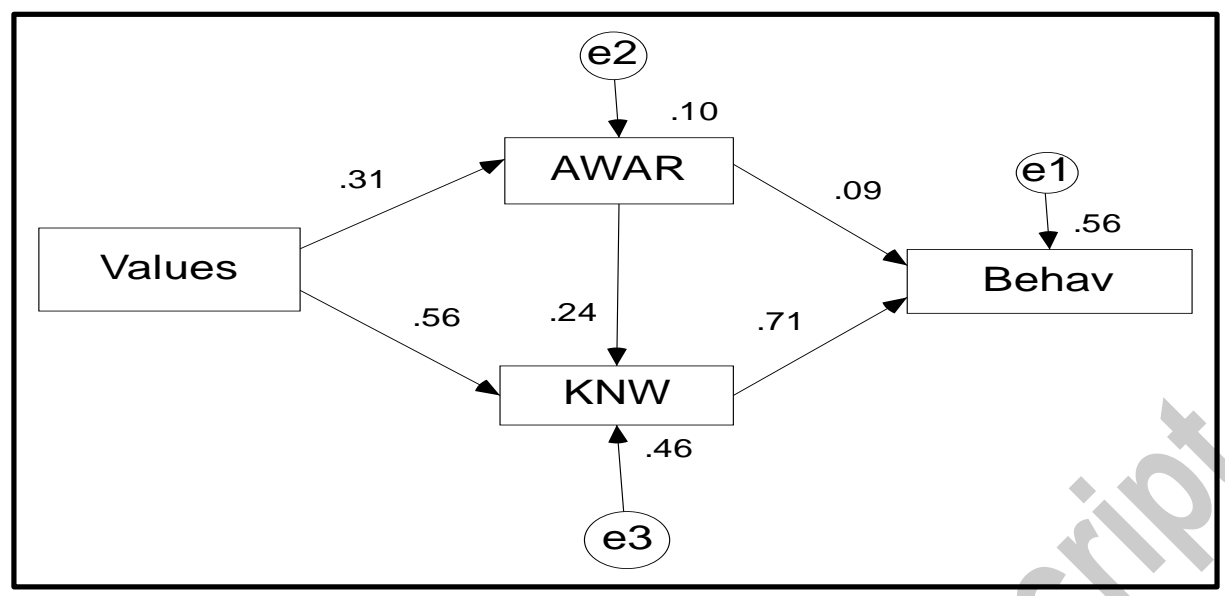

\section{Discussion and policy implications}

Hydrogen energy is expected to play an important role in developing a new energy infrastructure for the future. This expectation has come true in many developed countries that have already replaced a portion of their conventional energy with alternative fuels. As Malaysia considers how to replace its conventional energy, options for its future direction includes a low emission hydrogen-based transport system. While a gradual shift to hydrogen transportation is under consideration in the country, concerns remain over how to make such a transition, such as how to implement a support system that can enable this transition.

This study first used the Theory of Planned Behaviour model (TPB: Ajzen, 2002), with components such as environmental knowledge, environmental attitudes toward HFCVs, awareness of HFCVs, purchase intentions, and purchase behaviours toward HFCVs, to consider these concerns. Secondly, the study explored infrastructure development issues to understand how such a transition can be implemented and sustained.

HFCVs implementation issues in Malaysia span several fronts. This study categorizes these into three broad aspects: (i) technology adoption and economic obstacles, (ii) public acceptance of new technology and public preferences, and (iii) managing (to reach) a sustainable low carbon society target. Technological adoption challenges of HFCVs include safety standards, user costs, vehicle mileage, maintenance, as well as concerns related to public acceptance and the desire to own HFCVs. Economic obstacles include lack of resources, lack of a nationwide hydrogen infrastructure, lack of capacity, and poorly-developed support systems essential for HFCVs. 
In order to suggest possible ways of addressing these implementation challenges, this study considered how market demand for HFCVs can be promoted. Therefore, the following variables have been used (i) environmental values, knowledge and awareness, (ii) awareness of environmental subject matters, (iii) purchase intention and awareness, and (iv) purchase behavior responsiveness towards a low carbon society by introducing hydrogen fuel cell vehicles. The hypotheses' tests indicate that many in the sample decisively believe that HFCVs (compared to conventional vehicles) can help with overall environmental sustainability. Threshold values of all tests on first mediator of e1 $(\beta=0.56)$, e $2(\beta=0.10)$ and e $3(\beta=0.46)$ and second mediator on e3 ( $\beta=0.71)$, e1 $(\beta=0.56)$, and e2 $(\beta=0.24)$ support the idea that knowledge plays a significant role in influencing purchase behavior through, for example, awareness about the benefits of having HFCVs. Based on those observations, this study offers some recommendations that can help to transform such strategy choices into actions.

The promotion of HFCVs in Malaysia must be addressed by both demand side ${ }^{9}$ and supply side ${ }^{10}$ policies as illustrated in Figure 6. Ultimately, a balance of both approaches is likely to be best, whereby policymakers on both sides coordinate their efforts in the same direction and over roughly the same time period. However, to reach such a balance, demand side policies should focus on purchase intention issues. Policy strategy should be equipped with the depth knowledge on direction of perception intension and the quantification of awareness behavior. Thus, proper management of negative public attitudes and promotion of HFCVs acceptance is important for successful introduction of HFCVs. Without such a coordinated policy approach, consumers' concerns about the environment may not translate into a greater likelihood of purchasing a cleaner vehicle like a HFCV. Roche et al. (2010) acknowledged consumers' concerns and environment, and intensified demands of consumers for introduction of HFCVs. In an earlier study, Heffner et al. (2007) addressed consumers' concerns and environmental issues and emphasized how important demand-side consumer environmental behaviors and concerns are on shaping green technology preferences. By contrast, supply side policies should focus on innovation and removal of techno-economic obstacles, and promotion of $R \& D$ and

\footnotetext{
${ }^{9}$ Demand side policies aim to increase aggregate demand $(A D)$ in the economy through either contractionary or expansionary policies. Those polices are related to aggregate spending in the overall economy based on the economic situation.

${ }^{10}$ Supply side policies aim to increasing aggregate supply (AS) in the economy through productive capacities by improving the factor of production.
} 
commercialization, as those issues may reduce HFCVs demand due to concerns about uncertainties or safety concerns.

Figure 6: Demand side and supply side policy coordination

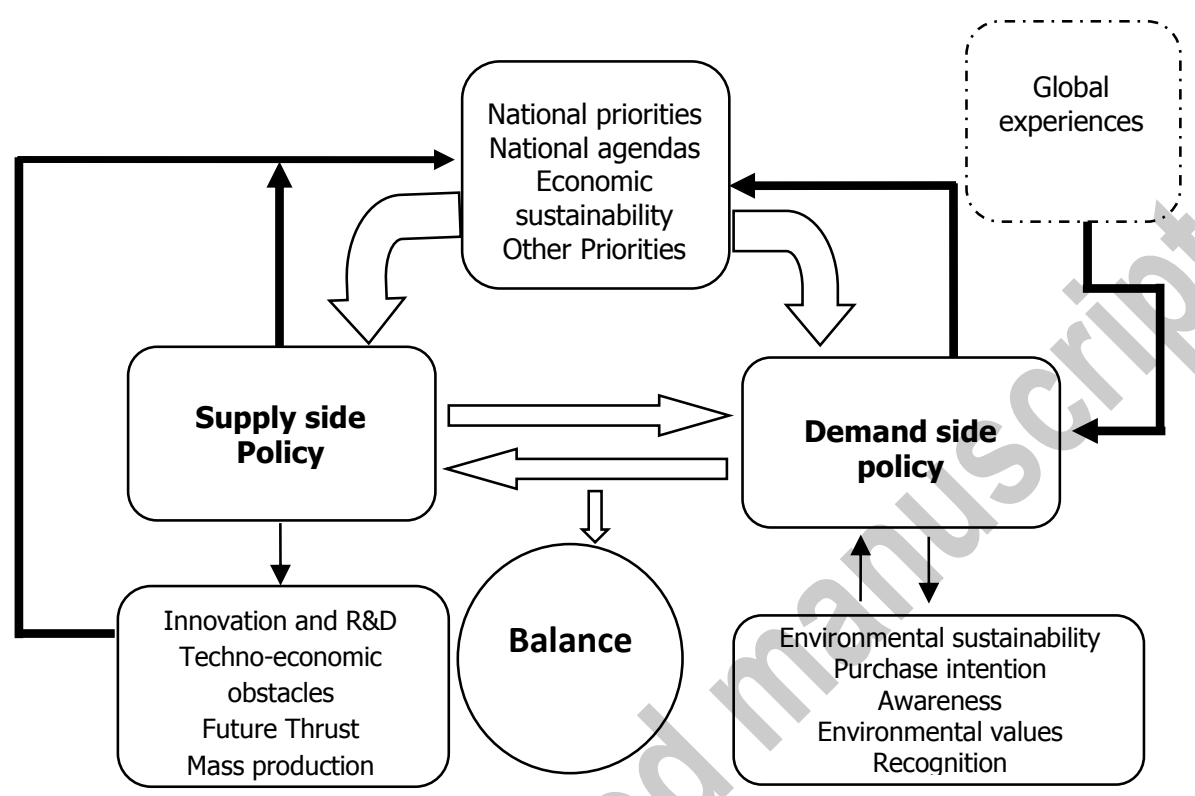

Policymakers must shape the conditions that create both demand and supply side policy options for HFCVs. Demand side policies should be intensified to create market demand for HFCVs that address purchase intention, awareness and gaps of public acceptance, recognition, preference, subjective norms, perceived behavior control and attitude towards HFCVs. This study's outcomes by public preference \& perceived behavioral issues could be a basis for strategy selections into actions. The study outcomes will help with the creation of both demand side and supply side policies and strategies. However, demand side options cannot work alone unless balanced by supply side options.

Thus, as indicated in Figure 7, this paper contends that policy guidance on hydrogen fuel cell vehicle implementation should be issued from top to bottom. Firstly, Malaysia's national low carbon pathway should be a starting point where sustainable transportation can support the national agenda for the achievement of economic and environmental goals. Secondly, national energy security concerns related to available national conventional energy resources will point towards technology options which support the expansion of alternative energy resources in 
national plans. With both supply and demand side policy support, it is anticipated that Malaysia will be able to meet the milestones agreed upon.

The policy plan and directions around HFCVs adoption should be formulated with both public and private support since it should be noted that not all consumers can afford a new technology unless a sustained affordability strategy is created. Gordon et al. (2012), in addressing policy priorities for advancing the U.S. electric vehicle market, state that effective policymaking must involve some sort of consultations with various stakeholders, including car makers, and this lesson can be a model for HFCVs advancement in Malaysia. At minimum, there are two elements of concern that must be solved: (i) affordability (i.e. compared to developed countries, how can consumers in developing countries like Malaysia afford HFCVs); and (ii) adaptability (i.e. developing countries with limited capacity may turn to alternative funding options such as climate finance, which requires international negotiations).

This paper contends that the national HFCVs implementation roadmap in Malaysia should be structured in a manner which overcomes: (i) technology adoption challenges and economic obstacles, and (ii) obstacles related to public acceptance of new technologies. If these can be overcome, public preferences for HFCVs technology may increase over time. The 2030 time frame is a reasonable goal to potentially have HFCVs in the market, and the approach outlined in this study will support the adoption of HFCVs over the medium and long terms. If there are no direct subsidies available from the government, as long as the technology is at least available in the market and enough resources are in place to support HFCVs implementation, the right balance of supply and demand side policies will coordinate by laissez faire economic theory.

Later, once full technology and mass production is in place, problems related to public acceptance, technology adoption, economic obstacles and public preferences should grow less over time. Besides, demands for HFCVs in Malaysia and perception of Malaysians on HFCVs would positively change if HFCVs become very popular in other advanced countries by 2030 . Likewise, demand side routes, including marketing strategies, would alter competition and selfpricing mechanisms by adding additional support systems for demand and supply conditions. The gradual development of HFCVs will regulate the market with self-pricing mechanisms stimulated by the entry of other competitors. Existing national mechanisms for low carbon pathway shifts toward green motorisation and enhanced plans for future movements in Malaysia 
would include HFCVs in long-term policies, further development strategies, and regulatory support frameworks.

It should be noted that the government of the East Malaysian state of Sarawak has launched a pilot project to introduce HFCVs as a form of sustainable transport. However, this is a state-level rather than national-level initiative, and currently, no blueprint exists to map out strategies for achieving the low carbon milestones laid out by the goals of the Paris Agreement.. Therefore, a regulatory framework ranging from technological innovation to optimal adaptive levels, and including public and private support is needed to address current gaps. This study suggests using both behavioral and policy approaches to find a likely balance between the low carbon pathways and policy responses (see Figure 7).

In summary, this study found that purchase intentions and purchase behaviors related to HFCVs are closely associated with environmental awareness \& values $(\beta=0.312)$, environmental knowledge \& awareness $(\beta=0.241)$, and purchase behavior \& environmental knowledge ( $\beta=0.709)$ in the sample surveyed, which confirm this study's hypotheses. However, the study also found that environmental knowledge plays a more significant role in influencing purchase behavior through awareness, as shown by e3 $(\beta=0.71)$, e1 $(\beta=0.56)$, and e2 $(\beta=0.24)$. Therefore, it the findings in the study sample are also found in the wider Malaysian population, it will be particularly important to consider demand side policy options as the first phase of action. For example, to maximize the impact of environmentalism on purchase behavior, demand side policies should be introduced initially to create market demand for HFCVs. Once the demand for HFCVs is established, this will create the opening for supply side policies, and eventually the balance between both demand and supply will create favorable market conditions that will support adoption of HFCVs.

This paper contends that the Federal Government's role is very important in leading the adoption of a new technology like HFCVs, where much support and effort are initially required, and strategically coordination of demand and supply side policies is needed (Figure 6). The government should incentivize demand side components such as purchase rebates, tax credits, sales tax waivers, registration fee reductions, low carbon fuel policies, and environmental awareness, and should showcase states which are leading for a substantial period of time on lowcarbon HFCVs adoption and the transition to transportation carbon pricing and zero-emission vehicle mandates. Determining which mix of incentives to use will depend on how quickly the 
costs of HFCVs decline. Selecting incentivizing options may also depend on how consumers respond to non-monetary and monetary incentives, which can vary by the demographics as indicated in Table 1. Policy makers must also propel supply side policies by developing a national plan, motivating HFCV manufacturers, extending HFCV policies to encourage industry support, providing import duty waivers and discount on raw materials, creating a national hydrogen blueprint that phases out conventional vehicles, and providing support for infrastructure development.

Figure 7: Suggested policy intervention and its relations to the Malaysian economy

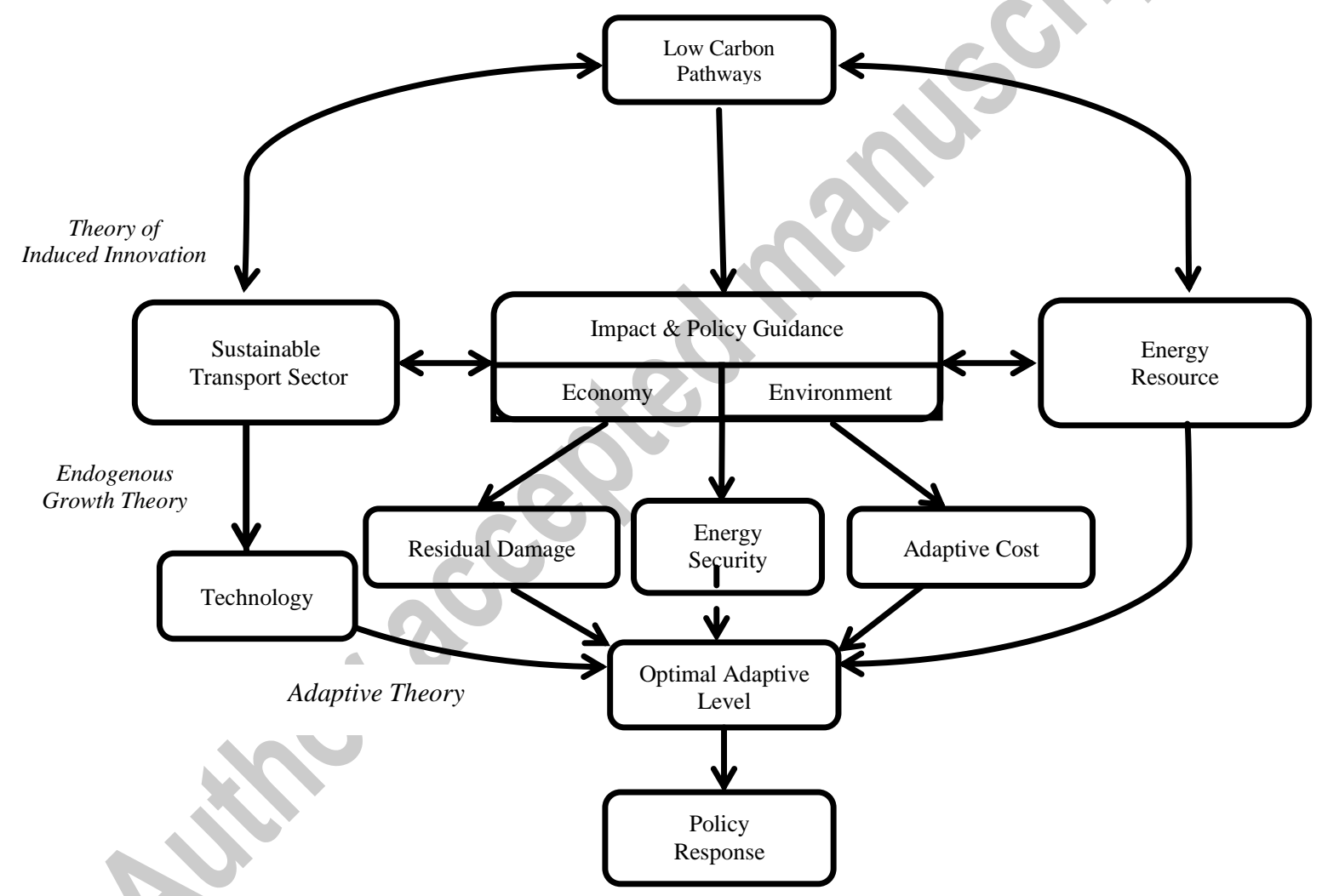

This study also acknowledges some limitations. Firstly, the sample is not very large (i.e. non representative of all drivers), so the findings obtained need to be contextualised. Secondly, the focus of the work area was only Malaysia, whereas it would be helpful to add other countries and a greater geographical coverage for further locating the factual nature of HFCV challenges. Finally, the self-report format of data used in this study can suffer from recall bias with participants misreporting their true behaviors and perceptions. Lastly, although anonymity was 
assured during the survey, respondents might have over-reported or under-reported on some questions, which could influence the findings. Future studies that are extensive and qualitative in nature would reduce the limitations indicated.

\section{Conclusion}

This study addresses the prospects and challenges of introducing hydrogen fuel cell vehicles in Malaysia and outlines how Malaysia can incorporate alternative greener technologies such as HFCVs as it maps low carbon pathways for its future. To have a factual vision for HFCVs, promising recommendations for implementing HFCVs include managing demand and supply side polices, while simultaneously following low carbon pathways and other national sustainability agendas. To assist in the selection of policy actions, this study tested likely challenges to HFCVs implementation against several related factors. Factors which were found to have significant impacts in favor of HFCV adoption included: environmental awareness toward values; environmental knowledge toward awareness; values toward environmental knowledge; behavior toward environmental awareness, and; behavior toward environmental knowledge. Those factors are categorized as components of demand side policies. By contrast, supportive supply side factors include technology, mass production, $\mathrm{R} \& \mathrm{D}$, cost of production, safety, subsidy issue, regulatory frameworks, and future demand are also framed for policy action. The main policy suggestion of this paper is that, while market-driven options may be good for long-run HFCVs adoption in Malaysia, in the short run, some degree of intervention by policy makers is required to counterbalance existing macroeconomic deterrents and to motivate consumer demand. Such interventions include: motivating consumers and HFCV manufacturers, public investment into research and development (R\&D), disincentives for conventional vehicles, incentives to own HFCVs, increasing awareness of the low-carbon path, transitioning to carbon pricing for conventional transportation, HFCVs registration fee reductions, low carbon fuel policy development, showcasing states which are leading on low-carbon HFCVs, and phasing out conventional cars gradually by regulating the established conventional vehicle market. This study considers the Malaysian context as a case study, nevertheless, these policy suggestions can potentially help in other countries where emissions from the transport sector are huge and the need for new energy options is a fundamental issue. 


\section{AUTHOR ACCEPTED MANUSCRIPT}

\section{References}

Adams, B. D., \& Chen, A. (2011). The role of palladium in a hydrogen economy. Materials today, 14(6), 282-289.

Ahmed, A., Al-Amin, A. Q., Ambrose, A. F., \& Saidur, R. (2016). Hydrogen fuel and transport system: A sustainable and environmental future. International journal of hydrogen energy, 41(3), 1369-1380.

Ajanovic, A., \& Haas, R. (2018). Economic prospects and policy framework for hydrogen as fuel in the transport sector. Energy Policy, 123, 280-288.

Ajzen, I. (2010). Constructing a TPB questionnaire: conceptual and methodological considerations. Available at: www-unix. oit. umass. edu.

Akhatar, M.N., Singh M.K., \& Kumar, S. (2014). Non-Conventional energy resources and technology. International Journal of Advanced Research and Technology, 2, 10-4.

Albayrak, T., Aksoy, Ş., \& Caber, M. (2013). The effect of environmental concern and scepticism on green purchase behaviour. Marketing Intelligence \& Planning, 31(1), 27-39.

Ambrose, A. F., Al-Amin, A. Q., Rasiah, R., Saidur, R., \& Amin, N. (2017). Prospects for introducing hydrogen fuel cell vehicles in Malaysia. International Journal of Hydrogen Energy, 42(14), 9125-9134.

Ambrose, A. F., Rasiah, R., Al-Amin, A. Q., \& Chen, Z. (2018). Introducing hydrogen fuel cell vehicles in Malaysia. Journal of the Asia Pacific Economy, 23(2), 263-278.

Andres, R. J., Boden, T. A., Bréon, F. M., Ciais, P., Davis, S., Erickson, D., ... \& Oda, T. (2012). A synthesis of carbon dioxide emissions from fossil-fuel combustion. Biogeosciences, 9(5), 1845-1871.

Arun, B., Pai, D., \& Chethan, K. N. (2018). Review on alternative propulsion in automotiveshybrid vehicles. International Journal of Engineering and Technology, 7(3), 1311-1319.

Axsen, J., \& Kurani, K. S. (2013). Hybrid, plug-in hybrid, or electric-What do car buyers want? Energy Policy, 61, 532-543.

Bae, J. H., \& Cho, G. L. (2010). A dynamic general equilibrium analysis on fostering a hydrogen economy in Korea. Energy Economics, 32, S57-S66.

Baland, J. M., Bardhan, P., \& Bowles, S. (Eds.). (2018). Inequality, cooperation, and environmental sustainability. Princeton University Press. 


\section{AUTHOR ACCEPTED MANUSCRIPT}

Ball, M., \& Wietschel, M. (Eds.). (2009). The hydrogen economy: opportunities and challenges. Cambridge University Press.

Barber, N., Kuo, P. J., Bishop, M., \& Goodman Jr, R. (2012). Measuring psychographics to assess purchase intention and willingness to pay. Journal of consumer marketing, 29(4), 280292.

Bataille, C., Åhman, M., Neuhoff, K., Nilsson, L. J., Fischedick, M., Lechtenböhmer, S., ... \& Sartor, O. (2018). A review of technology and policy deep decarbonization pathway options for making energy-intensive industry production consistent with the Paris Agreement. Journal of Cleaner Production, 187, 960-973.

Beeton, D., \& Meyer, G. (2014). Electric Vehicle Business Models. Springer: Heidelberg, Germany.

Bekun, F. V., Alola, A. A., \& Sarkodie, S. A. (2019). Toward a sustainable environment: Nexus between $\mathrm{CO} 2$ emissions, resource rent, renewable and nonrenewable energy in 16-EU countries. Science of The Total Environment, 657, 1023-1029.

UNFCCC. (2017). Joint Statement Issued at the Conclusion of the 25th BASIC Ministerial Meeting on Climate Change - Headquarters of the UNFCCC, 13. Bonn, Germany.

Bonnafous, A., \& Raux, C. (2003). Transport energy and emissions: rail. In: Hensher, D.A., Button, K.J. (Eds.), Handbooks in Transport 4: Handbook of Transport and the Environment. Elsevier, pp. 293-308.

Bulkeley, H., \& Newell, P. (2015). Governing climate change. Routledge.

Chen, T. Y., Huang, D. R., \& Huang, A. Y. J. (2016). An empirical study on the public perception and acceptance of hydrogen energy in Taiwan. International journal of green energy, 13(15), 1579-1584.

Chen, Y., \& Perez, Y. (2018). Business model design: lessons learned from Tesla Motors. In Towards a Sustainable Economy (pp. 53-69). Springer, Cham.

Christoff, P. (2016). The promissory note: COP 21 and the Paris Climate Agreement. Environmental Politics, 25(5), 765-787.

COP21. (2015). 21st conference of the Parties on climate change 2015, Paris.

Cropper, M. A., Geiger, S., \& Jollie, D. M. (2004). Fuel cells: a survey of current developments. Journal of Power Sources, 131(1-2), 57-61. 
De Jesus, A., \& Mendonça, S. (2018). Lost in transition? Drivers and barriers in the ecoinnovation road to the circular economy. Ecological Economics, 145, 75-89.

Den Elzen, M., Admiraal, A., Roelfsema, M., van Soest, H., Hof, A. F., \& Forsell, N. (2016). Contribution of the G20 economies to the global impact of the Paris agreement climate proposals. Climatic Change, 137(3-4), 655-665.

Devine-Wright, P. (2007). Reconsidering public attitudes and public acceptance of renewable energy technologies: a critical review. Beyond Nimbyism: a multidisciplinary investigation of public engagement with renewable energy technologies, 15.

Dia, H., Taylor, M., Stone, J., Somenahalli, S., \& Cook, S. (2019). Low Carbon Urban Mobility. In Decarbonising the Built Environment (pp. 259-285). Palgrave Macmillan, Singapore.

Dinse, G. (1999). Wasserstoffahrzeuge und ihr Funktionsraum - Eine Analyse der technischen, politisch-rechtlichen und sozialen Dimensionen (Hydrogen vehicles and their ambiance An analysis of the technical, political and social dimensions), Institut für Mobilitätsforschung Charlottenstr.43, 10117 Berlin, Germany.

DOS. (2017). Economic and various dataset. Department of Statistics, Putrajaya, Malaysia.

Eberle, U., Müller, B., \& von Helmolt, R. (2012). Fuel cell electric vehicles and hydrogen infrastructure: status 2012. Energy \& Environmental Science, 5(10), 8780-8798.

Economic Planning Unit. 2011. Malaysia, Eleventh Malaysia plan (11th MP), Putrajaya, Malaysia.

EIA. (2017). Transportation sector energy consumption. EIA energy outlook, 2016.

Ekins, P. (2010). Hydrogen energy: economic and social challenges. Earthscan.

Emonts, B., Schiebahn, S., Görner, K., Lindenberger, D., Markewitz, P., Merten, F., \& Stolten, D. (2017). Re-energizing energy supply: Electrolytically-produced hydrogen as a flexible energy storage medium and fuel for road transport. Journal of Power Sources, 342, 320-326.

European Parliament. (2016). Outcomes of COP22 Climate Change Conference. donwloaded from file:///C:/Users/user/Downloads/EPRS_ATA(2016)593547_EN \%20(1).pd. (Access date on April 4, 2017).

Fankhauser, S., \& Jotzo, F. (2018). Economic growth and development with low-carbon energy. Wiley Interdisciplinary Reviews: Climate Change, 9(1), e495.

Fast, S. (2013). Social acceptance of renewable energy: Trends, concepts, and geographies. Geography Compass, 7(12), 853-866. 


\section{AUTHOR ACCEPTED MANUSCRIPT}

Fridahl, M., \& Linnér, B. O. (2016). Perspectives on the Green Climate Fund: possible compromises on capitalization and balanced allocation. Climate and Development, 8(2), 105-109.

Gnann, T., Funke, S., Jakobsson, N., Plötz, P., Sprei, F., \& Bennehag, A. (2018). Fast charging infrastructure for electric vehicles: Today's situation and future needs. Transportation Research Part D: Transport and Environment, 62, 314-329.

Gordon, D., Sperling, D., \& Livingston, D. (2012). Policy priorities for advancing the US electric vehicle market(Vol. 17). Carnegie Endowment for International Peace, Washington, D.C. USA.

Gutiérrez, F., \& Méndez, F. (2012). Entropy generation minimization for the thermal decomposition of methane gas in hydrogen using genetic algorithms. Energy conversion and management, 55, 1-13.

Hannan, M. A., Azidin, F. A., \& Mohamed, A. (2014). Hybrid electric vehicles and their challenges: A review. Renewable and Sustainable Energy Reviews, 29, 135-150.

Heffner, R. R., Kurani, K. S., \& Turrentine, T. S. (2007). Symbolism in California's early market for hybrid electric vehicles. Transportation Research Part D: Transport and Environment, 12(6), 396-413.

Hensher, D. A. (2008). Climate change, enhanced greenhouse gas emissions and passenger transport-What can we do to make a difference? Transportation Research Part D: Transport and Environment, 13(2), 95-111.

IEA. (2015). Technology Roadmap Hydrogen Fuel Cells. Retrived from https://www.iea.org/ publications/freepublications/publication/TechnologyRoadmapHydrogenandFuelCells.pd $\mathrm{f}$

Ismail, T. M., Ramzy, K., Abelwhab, M. N., Elnaghi, B. E., El-Salam, M. A., \& Ismail, M. I. (2018). Performance of hybrid compression ignition engine using hydroxy (HHO) from dry cell. Energy Conversion and Management, 155, 287-300.

Kline, RB. (2010). Principles and practice of structural equation modeling, 3rd edn. Guilford, New York.

Li, Y., Zhan, C., de Jong, M., \& Lukszo, Z. (2016). Business innovation and government regulation for the promotion of electric vehicle use: lessons from Shenzhen, China. Journal of cleaner production, 134, 371-383. 


\section{AUTHOR ACCEPTED MANUSCRIPT}

Lomax, R. G., \& Schumacker, R. E. (2004). A beginner's guide to structural equation modeling. Psychology press.

MacLean, H. L., Lave, L. B., \& Griffin, W. M. (2004). Alternative transport fuels for the future. International journal of vehicle design, 35(1-2), 27-49.

Manthiram, A. (2016). Electrical energy storage: materials challenges and prospects. MRS Bulletin, 41(8), 624-631.

Marbán, G., \& Valdés-Solís, T. (2007). Towards the hydrogen economy?. International Journal of Hydrogen Energy, 32(12), 1625-1637.

Moliner, R., Lázaro, M. J., \& Suelves, I. (2016). Analysis of the strategies for bridging the gap towards the Hydrogen Economy. International journal of hydrogen energy, 41(43), 1950019508.

Moriarty, P., \& Honnery, D. (2019). Prospects for hydrogen as a transport fuel. International Journal of Hydrogen Energy, 44(31),16029-16037.

Narayanan, S. R., Prakash, G. S., Manohar, A., Yang, B., Malkhandi, S., \& Kindler, A. (2012). Materials challenges and technical approaches for realizing inexpensive and robust iron-air batteries for large-scale energy storage. Solid State Ionics, 216, 105-109.

Nian, V., Hari, M. P., \& Yuan, J. (2019). A new business model for encouraging the adoption of electric vehicles in the absence of policy support. Applied energy, 235, 1106-1117.

Nowotny, J., Dodson, J., Fiechter, S., Gür, T. M., Kennedy, B., Macyk, W., ... \& Rahman, K. A. (2018). Towards global sustainability: Education on environmentally clean energy technologies. Renewable and Sustainable Energy Reviews, 81, 2541-2551.

O’Dwyer, E., Pan, I., Acha, S., \& Shah, N. (2019). Smart energy systems for sustainable smart cities: Current developments, trends and future directions. Applied energy, 237, 581-597.

Oh, T. H., Hasanuzzaman, M., Selvaraj, J., Teo, S. C., \& Chua, S. C. (2018). Energy policy and alternative energy in Malaysia: Issues and challenges for sustainable growth-An update. Renewable and Sustainable Energy Reviews, 81, 3021-3031.

Preuster, P., Papp, C., \& Wasserscheid, P. (2016). Liquid Organic Hydrogen Carriers (LOHCs): Toward a Hydrogen-free Hydrogen Economy. Accounts of Chemical Research, 50(1), 74-85.

Randolph, J., \& Masters, G. M. (2018). Energy for Sustainability: Foundations for Technology, Planning, and Policy. Island Press. 


\section{AUTHOR ACCEPTED MANUSCRIPT}

Rasiah, R., Al-Amin, A. Q., Ahmed, A., Leal Filho, W., \& Calvo, E. (2016). Climate mitigation roadmap: assessing low carbon scenarios for Malaysia. Journal of cleaner production, 133, 272-283.

Rasiah, R., Al-Amin, A. Q., Chowdhurry, A. H., Ahmed, F., \& Zhang, C. (2018). Climate change mitigation projections for ASEAN. Journal of the Asia Pacific Economy, 23(2), 195212.

Rasiah, R., Al-Amin, A. Q., Habib, N. M., Chowdhury, A. H., Ramu, S. C., Ahmed, F., \& Leal Filho, W. (2017). Assessing climate change mitigation proposals for Malaysia: Implications for emissions and abatement costs. Journal of Cleaner Production, 167, 163173.

Raslavičius, L., Azzopardi, B., Keršys, A., Starevičius, M., Bazaras, Ž., \& Makaras, R. (2015). Electric vehicles challenges and opportunities: Lithuanian review. Renewable and Sustainable Energy Reviews, 42, 786-800.

Reckien, D., Salvia, M., Heidrich, O., Church, J. M., Pietrapertosa, F., De Gregorio-Hurtado, S., ... \& Orru, H. (2018). How are cities planning to respond to climate change? Assessment of local climate plans from 885 cities in the EU-28. Journal of cleaner production, 191, 207-219.

Roberts, C., Geels, F. W., Lockwood, M., Newell, P., Schmitz, H., Turnheim, B., \& Jordan, A. (2018). The politics of accelerating low-carbon transitions: Towards a new research agenda.

Roche, M. Y., Mourato, S., Fischedick, M., Pietzner, K., \& Viebahn, P. (2010). Public attitudes towards and demand for hydrogen and fuel cell vehicles: A review of the evidence and methodological implications. Energy policy, 38(10), 5301-5310.

Sarkar, M. S. K., Al-Amin, A. Q., \& Leal Filho, W. (2019). Revisiting the social cost of carbon after INDC implementation in Malaysia: 2050. Environmental Science and Pollution Research, 26(6), 6000-6013.

Silva, C. M., Ferreira, A. F., \& Bento, J. P. C. (2014). Impact of hydrogen in the road transport sector for Portugal 2010-2050. Energy Procedia, 58, 207-214.

Singh, S., Jain, S., Venkateswaran, P. S., Tiwari, A. K., Nouni, M. R., Pandey, J. K., \& Goel, S. (2015). Hydrogen: A sustainable fuel for future of the transport sector. Renewable and Sustainable Energy Reviews, 51, 623-633.

Smith, F. (2019). Environmental Sustainability: Practical Global Applications. CRC Press. 


\section{AUTHOR ACCEPTED MANUSCRIPT}

Staffell, I., Scamman, D., Abad, A. V., Balcombe, P., Dodds, P. E., Ekins, P., ... \& Ward, K. R. (2019). The role of hydrogen and fuel cells in the global energy system. Energy \& Environmental Science, 12(2), 463-491.

Stobart, R. K. (1999). Fuel Cell Power for Passenger Cars-What Barriers Remain? (No. 1999-010321). SAE Technical Paper.

Thiele, L. (2019). Ceteris Paribus Ideology: The Green Economy, Technology and the Future of Work. Contours of the Illiberal State: Governing Circulation in the Smart Economy, 245.

Timilsina, G. R., \& Shrestha, A. (2009). Transport sector CO2 emissions growth in Asia: Underlying factors and policy options. Energy policy, 37(11), 4523-4539.

Tollefson, J., \& Weiss, K. R. (2015). Nations approve historic global climate accord. Nature News, 528(7582), 315.

Tolliver, C., Keeley, A. R., \& Managi, S. (2019). Green bonds for the Paris agreement and sustainable development goals. Environmental Research Letters, 14(6), 064009.

VanGelder, K. (2017). Fundamentals of Automotive Technology. Jones \& Bartlett Learning.

Wang, J. H., Chiang, W. L., \& Shu, J. P. (2000). The prospects-fuel cell motorcycle in Taiwan. Journal of power sources, 86(1-2), 151-157.

Wanitschke, A., \& Hoffmann, S. (2019). Are battery electric vehicles the future? An uncertainty comparison with hydrogen and combustion engines. Environmental Innovation and Societal Transitions, in press. https://doi.org/10.1016/j.eist.2019.03.003.

Whittingham, M. S. (2008). Materials challenges facing electrical energy storage. Mrs Bulletin, 33(4), 411-419.

World Bank. (2016). CO2 emissions (metric tons per capita), WB, USA.

Zambrano-Gutiérrez, J. C., Nicholson-Crotty, S., Carley, S., \& Siddiki, S. (2018). The Role of Public Policy in Technology Diffusion: The Case of Plug-in Electric Vehicles. Environmental science \& technology, 52(19), 10914-10922. 


\section{APPENDIX}

\section{A. Validation of Measurement Model}

As addressed in other studies, Validation of model appropriateness is important for accurate study outcomes, as some hidden variables can affect findings (Kline, 2010; Hair et al. 2011). Thus, some measurements such as Absolute Fit Index (e.g. RMR and GFI), Incremental Fit Index (e.g. CFI and NFI) and Parsimony Fit Index (e.g. $\chi 2 / \mathrm{df})$ have been tested. The fit indices show that the model fits the data. The normed chi-square $\chi 2 / \mathrm{df}=1.00$ which is below the recommended cut-off point of 5 to reflect good model fit. Also CFI of 0.873 and RMR 0.038 indicated that the data fit the model well (Byrne, 2013; Hair et al., 2010). The model-fit- indices for the model were statistically significant at the $.001 \%$ level and the relative recommended thresholds presented well. The values of GFI (0.901) and NFI (0.892) were very close to threshold value. The model-fit indices' results are summarized in Table 1A. The model summary as indicated in Table 4 shows a presence of absolute, incremental and parsimony fit. The results supported by the related studies indicated by Hair et al (2010) and Chinna (2009).

Table 1A. Fitness of Research Model

\begin{tabular}{llll}
\hline Model Fit Indices & Threshold & \multicolumn{2}{l}{ Observed } \\
& Value & $\begin{array}{l}\text { value for } \\
\text { Measurement } \\
\text { Model }\end{array}$ \\
\hline Absolute Fit Index & & \\
RMR & $\leq 0.10$ & 0.038 \\
GFI & $\geq 0.90$ & 0.908 \\
Incremental Fit Index: & & \\
CFI & $\geq 0.90$ & 0.900 \\
NFI & $\geq 0.90$ & 0.900 \\
Parsimony Fit Index & & \\
$\chi^{2} / d f$ & $\leq 5.0$ & 1.000 \\
\hline
\end{tabular}




\section{AUTHOR ACCEPTED MANUSCRIPT}

\section{B. Abbreviations}

$\begin{array}{ll}\text { AWAR } & \text { Awareness } \\ \text { BEHAV } & \text { Behavior } \\ \text { COP } & \text { Conference on Climate Change } \\ \text { EIA } & \text { Energy Information Administration (United States) } \\ \text { EV } & \text { Electric vehicles } \\ \text { GHG } & \text { Greenhouse Gases } \\ \text { HFCV } & \text { Hydrogen Fuel Cell Vehicles } \\ \text { INDCs } & \text { Intended Nationally Determined Contributions } \\ \text { KNW } & \text { Knowledge } \\ \text { OECD } & \text { Organization for Economic Co-operation and Development } \\ \text { PB } & \text { Purchase behavior } \\ \text { PI } & \text { Purchase intention } \\ \text { R\&D } & \text { Research and Development } \\ \text { SEM } & \text { Structural Equation Modelling } \\ \text { SN } & \text { Subjective Norms } \\ \text { TPB } & \text { Theory of Planned Behavior } \\ \text { UNFCCC } & \text { United Nations Framework Convention on Climate Change }\end{array}$

